\title{
PENERAPAN TECHNOLOGY ACCEPTANCE MODEL PADA PENGGUNAAN E-MONEY STUDI PADA WILAYAH NON PERKOTAAN
}

\author{
Yuni Nustini \\ Universitas Islam Indonesia \\ 903120102@uii.ac.id \\ Annisa H. Adhinagari \\ Universitas Islam Indonesia \\ ebbaannisa@gmail.com
}

\begin{abstract}
Abstrak: Penerapan Technology Acceptance Model pada Penggunaan e-Money Studi pada Wilayah Non-Perkotaan. Studi ini bertujuan untuk mengetahui faktor-faktor yang mempengaruhi warga di wilayah non-perkotaan dalam menggunakan e-money (uang elektronik). Penelitian ini penting untuk dilaksanakan mengingat pemerintah telah mencanangkan cash less society. Di duga saat ini secara masyarakat Indonesia yang berdomisili di wilayah non-perkotaan belum terbiasa menggunakan $e$ money. Sampel dikumpulkan secara acak (random) dari orang-orang yang berdomisili di Kabupaten Sleman DIY dan dipilih dengan kriteria yang telah menggunakan e-money. Analisis data dengan regresi linier berganda di uji menggunakan software SPSS. Hasil pengujian data menunjukkan bahwa semua (empat) hipotesis didukung. Penelitian ini menyimpulkan bahwa selain masyarakat perkotaan, masyarakat non-perkotaan juga memiliki persepsi yang baik dan menerima pemakaian e-money sebagai alat pembayaran. Dengan demikian program cash less society yang dicanangkan oleh pemerintah RI akan didukung sepenuhnya oleh masyarakat Indonesia.
\end{abstract}

Kata kunci: e-Money, Cash Less Society, Technology Acceptance Model

Abstract: Technology Acceptance Model to Study the Use of e- Money in District Area. This study aims to determine the factors that influence citizens in non-urban areas in using e-money (electronic money). Considering that the government has launched a cash less society, this research was important to be carried out. The researcher suspected that currently Indonesian people who live in non-urban areas were not accustomed to using e-money. Samples were collected randomly from people who live in Sleman district, DIY and were selected by a criterion for those who had been used e-money. The multiple linear regression analysis was tested using SPSS software. The results of hypothesis testing showed that all (four) hypotheses were supported. Finally, this study concludes that instead of urban communities, non-urban communities also have a good perception and agree to use e-money to make payments. Thus the program of cash less society launched by the Indonesian government will be fully supported by all of the Indonesian citizens.

Keywords: e-Money, Cash Less Society, Technology Acceptance Model

\section{PENDAHULUAN}

Teknologi informasi yang didukung dengan internet telah merubah cara orang melakukan bisnis. Hampir semua sektor kehidupan termasuk bisnis saat ini sangat mengandalkan teknologi termasuk internet untuk melancarkan proses bisnisnya. Tidak dipungkiri lagi dukungan teknologi pada sector perbankan dan perdagangan. Sudah sangat merebak berbagai macam transaksi perbankan dan perdagangan dilakukan secara 


\section{Nominal: Barometer Riset Akuntansi dan Manajemen}

P-ISSN: 2303-2065 E-ISSN: 2502-5430

Volume 9 No 2 (2020)

elektronis berbasis teknologi digital. saat dapat digunakan sebagai alat

Teknologi informasi termasuk internet telah memberi peluang besar melakukan inovasi pada layanan dan penciptaan produk baru perbankan (Rizqiah \& Lubis, 2017). Salah satu bentuk produk dan layanan perbankan yang baru yang mengandalakan TI dan internet dan saat ini telah banyak dimanfaatkan masyarakat adalah uang elektronik.

Uang elektronik atau $e$-money adalah alat pembayaran elektronis dengan menggunakan sebuah kartu pintar atau menggunakan teknologi lainnya misalnya $Q R$ Code. Emoney menggunakan teknologi kartu pintar yang memiliki chip dan prosesor sehingga data atau transaksi dapat disimpan dan diproses misalnya melakukan pengkreditan, pendebitan dana atau memperbaharui informasi lainnya (Akinola, 2012). E-money dalam berbagai penelitian dinyatakan telah mempermudah konsumen ketika bertransaksi. Peraturan Bank Indonesia (PBI) No. 11/12/PBI/2009 adalah landasan yang mengatur ijin pemakaian dan berbagai ketentuan pemanfaatan e-money (revisi terakhir: PBI No. 18/17/PBI/2016).

Secara umum, pembayaran non-tunai memberi banyak manfaat kepada pemakai dan pemerintah. Bagi pemakai dengan digunakannya e-money resiko kehilangan uang tunai telah terhindarkan, sebab dana tersimpan didalam kartu elektronis dan setiap pembayaran resmi. Bagi pemerintah, apabila sebagian besar masyarakat telah menggunakan e-money, maka jumlah uang beredar dapat dikendalikan oleh Bank Indonesia sehingga inflasi dapat ditekan. Selain itu, Bank Indonesia akan menghemat biaya pencetakan uang serta meminimalkan jumlah uang rusak yang memerlukan dana Rp 3,5 triliun setiap tahunnya. Aryanto (2017) direktur True Money Indonesia menyatakan bahwa pada tahun 2017 Bank Indonesia telah mengeluarkan 21 lisensi $e$ money kepada beberap institusi yang sebagian besar dimiliki institusi perbankan (Cashless Society).

Survey tentang e-money di Indonesia telah dilakukan oleh beberapa lembaga survey seperti Alvara Research Center, Ipsos Indonesia, FT Confidential Research Mobile Payment dan Otoritas Jasa Keuangan (OJK) (Setyowati, 2019) dengan lokasi penelitian kota-kota besar di Indonesia. Selain dari pada itu, mendekati $70 \%$ responden survei tersebut berasal dari Jawa dan hanya 30\% mewakili daerah luar Jawa. Diketahui bahwa tingkat pengetahuan, pendidikan penduduk, serta berbagai fasilitas infrastruktur daerah luar Jawa belum sebaik Pulau Jawa, oleh karena itu ketika sebuah survei menemukan bahwa sebanyak 70,63\% responden mengaku paham dengan layanan keuangan digital sangat bisa dipahami. Hasil 70,63\% tersebut 


\section{Nominal: Barometer Riset Akuntansi dan Manajemen}

P-ISSN: 2303-2065 E-ISSN: 2502-5430

Volume 9 No 2 (2020)

tidak jauh berbeda dengan jumlah responden yang berasal dari kota-kota besar di Jawa.

Sejalan dengan data di atas, maka dapat dipahami bawa data Bank Indonesia (BI) menunjukkan sepanjang tahun 2018 nilai transaksi e-money di Indonesia mencapai $\mathrm{Rp}$ 47,2 triliun yaitu melonjak 281,39\% atau mendekati tiga kali lipat transaksi tahun 2017 yang bernilai Rp 12,4 triliun. Sampai dengan Juli 2019 nilai transaksi $e$-money sudah lebih dari Rp 69 triliun. Peningkatan transaksi uang elektronik sejalan dengan program Gerakan Nasional Non Tunai (GNNT) yang dicanangkan oleh BI sejak 2014.

Penelitian ini dilakukan di sebuah wilayah non-kota besar, di sebuah kabupaten di Propinsi Daerah Istimewa Yogyakarta (DIY). DIY dikenal sebagai miniatur Indonesia karena menjadi tempat tujuan belajar bagi masyarakat dari seluruh wilayah Indonesia. Selama ini, penelitian dengan topik e-money di Indonesia selalu dilaksanakan di kota-kota besar. Penelitian pada wilayah kabupaten non-perkotaan diharapkan dapat melengkapi dan menyempurnakan hasil penelitian yang telah lebih dahulu dilaksanakan dengan seting kota-kota besar. Lebih jauh lagi, penelitian ini ingin mengetahui persepsi dan penerimaan masyarakat non-perkotaan atas pendekatan cash less yang telah dicanangkan pemerintah. Kabupaten Sleman DIY dipilih sebagai lokasi penelitian karena merepresentasikan sebuah wilayah bukan kota dan karena jumlah penduduk kabupaten ini mendominasi jumlah penduduk DIY (sepertiga) sehingga diasumsikan merupakan miniatur (merepresentasikan) Indonesia.

Keberhasilan pemakaian e-money di Indonesia sebagai bentuk usaha penerapan cash less society dapat ditelaah dengan teori TAM (Technology Accepted Model). TAM merupakan model perilaku orang dari pemanfaatan inovasi teknologi informasi. TAM berfokus pada sikap pemakaian teknologi informasi oleh pemakai dengan mengembangkannya berdasarkan persepsi manfaat dan kemudahan (Davis et al., 1989).

Riset bersama oleh Daily Social dan Otoritas Jasa Keuangan (OJK) menemukan alasan sehingga orang mulai menyukai menggunakan layanan keuangan digital, yaitu kemudahan dalam penggunaan (74,9\%); simpel (71\%); efisiensi waktu $(62,7 \%)$; tidak perlu repot pergi ke bank $(48,9 \%)$; lebih aman (36,4\%); adanya promo dan insentif $(36,4 \%)$; serta, pengelolaan yang lebih baik (29,8\%) (Setyowati, 2019).

Sebelum survey di atas, pada 2016 penelitian Fadhli dan Fachruddin (2016) menjelaskan bahwa persepsi kebermanfaatan, persepsi kemudahan, kepercayaan, dan persepsi resiko memiliki pengaruh terhadap pemakaian internet banking. Selanjutnya pada 2017, penelitian Diptha menyimpulkan adanya pengaruh 


\section{Nominal: Barometer Riset Akuntansi dan Manajemen}

P-ISSN: 2303-2065 E-ISSN: 2502-5430

Volume 9 No 2 (2020)

variable kebermanfaatan, kemudahan, kepercayaan, kualitas produk, dan resiko terhadap kepuasan pegawai menggunakan $e$ money yang dikeluarkan oleh Bank BCA (Flazz Card).

Berdasarkan latar belakang beserta telaah hasil penelitian sebelumnya, penelitian ini bertujuan untuk melengkapi hasil penelitian dengan mengkonfirmasi pengaruh persepsi kebermanfaatan, persepsi kemudahan penggunaan, dapat dipercaya dan persepsi atas resiko terhadap pemakaiaan e-money khususnya di area non-perkotaan.

\section{KAJIAN LITERATUR}

Technology Acceptance Model (TAM) atau Model Penerimaan Teknologi. TAM pertama dikembangkan oleh Davis (1989) berdasarkan model Theory of Reasoned Action (TRA). Dalam TAM, penerimaan pengguna dalam penggunaan sistem informasi dipengaruhi oleh dua variabel, yaitu kegunaan (perceived usefulness) dan kemudahan penggunaan (perceived ease of use).

Bank for International Settlement (Peraturan Bank Indonesia No. 11/12/PBI/2009 Tanggal 13 April 2009 Tentang Uang Elektronik, 2009) mendefinisikan e-money sebagai produk stored-value atau prepaid card dimana sejumlah nilai uang (monetary value) disimpan secara elektronis dalam suatu peralatan elektronis. Nilai elektronis dapat diperoleh dengan menyetorkan sejumlah uang tunai atau dengan pendebitan rekeningnya di bank untuk kemudian disimpan dalam peralatan elektronis. Dengan peralatan tersebut, pemiliknya dapat melakukan pembayaran atau menerima pembayaran, dimana nilainya akan berkurang pada saat digunakan untuk melakukan pembayaran atau bertambah jika menerima pembayaran atau pada saat pengisian kembali.

Pengertian persepsi dalam Khakim (2016) dirujuk sebagai proses pengorganisasian, penginterpretasian terhadap rangsang yang diterima oleh organisme atau individu sehingga merupakan sesuatu yang berarti dan merupakan aktivitas yang integrated dalam diri individu.

Persepsi pemakaian adalah situasi ketika seseorang memberikan pendapat atas sesuatu yang dipakai atau digunakannya, misalnya suka atau tidak suka, sesuai atau tidak sesuai, atau pendapat/perasaan lainnya atas pemakaian sesuatu. Ketika e-money mulai dipakai sebagai sebuah sebuah cara baru untuk bertransaksi (melakukan pembayaran), pemakai merespon dengan berbagai pendapat, misalnya dari segi kemudahan, kebermanfaatan, resiko yang ditimbulkan, dan tingkat kepercayaan. Apabila pendapat masyarakat terhadap E-money baik, maka sebagai sebuah system yang baru e-money 


\section{Nominal: Barometer Riset Akuntansi dan Manajemen}

P-ISSN: 2303-2065 E-ISSN: 2502-5430

Volume 9 No 2 (2020)

sukses diterapkan. Saat ini e-money telah banyak diterbitkan oleh lembaga keuangan dan perbankan. Pengukuran Pemakaian $e$ money dimodifikasi dari penelitian Idris (2013) yang meliputi: keinginan penggunaan, frekuensi penggunaan, dan keberlangsungan pemakaian e-money di masa yang akan datang.

Dalam TAM, Davis (1989) menjelaskan bahwa perceived usefulness (persepsi kebermanfaatan) merupakan ukuran keyakinan seseorang bahwa teknologi dapat membantu meningkatkan hasil dari aktifitasnya (kinerja). Penelitian ini mengukur variabel ini dengan memodifikasi instrument penelitian dari Fadhli dan Fachruddin (2016) yang meliputi: produktivitas, efektifitas, dan kinerja sebuah aktivitas, tingkat pentingnya aktivitas, dan kebermanfaatan secara keseluruhan.

Menurut Jogiyanto (2007) persepsi kemudahan penggunaan (perceived ease of use) didefinisikan sebagai tingkat keyakinan seseorang bahwa dengan menggunakan suatu teknologi seseorang akan terbebas dari sebuah usaha, dan teknologi dapat dengan mudah dipahami serta digunakan. Seseorang bersedia menggunakan system dan teknologi baru karena yakin bahwa sistem dan teknologi tersebut mudah digunakan. Sementara orang tidak akan bersedia menggunakannya apabila yakin bahwa sistem dan teknologi tersebut tidak mudah digunakan. Pengukuran variabel ini dimodifikasi dari penelitian Diptha (2017) yang meliputi: mudah dipelajari dan digunakan, jelas serta mudah dipahami, mudah untuk menjadi mahir dalam menggunakannya.

Rafiq (2008) mengutip bahwa kepercayaan mempunyai dua elemen yaitu kredibilitas dan kejujuran. Kredibilitas berawal dari keyakinan akan suatu keahlian mitranya untuk melakukan tugas secara efektif dan dapat diandalkan. Sedangkan kejujuran merupakan suatu keyakinan bahwa maksud dan motivasi mitranya akan membawa keuntungan untuk bersama dan tidak akan melakukan tindakan yang akan berpengaruh negatif atau merugikan.

Kepercayaan merupakan kepekaan seseorang atas tindakan orang lain dengan harapan bahwa orang lain tersebut akan melakukan suatu tindakan kepada orang yang mempercayainya tanpa harus dilakukan pengawasan dan pengendalian. Pengukuran variabel ini memodifikasi instrument penelitian dari penelitian Sekarini., dkk (2016) yang terdiri atas: ukuran kemampuan, perbuatan baik, dan integritas.

Persepsi risiko adalah persepsi atas ketidakpastian dan konsekuensi yang akan dihadapi setelah melakukan aktivitas tertentu (Hsu \& Chiu, 2004; Pavlou, 2001); dalam konteks ini, merupakan ukuran pribadi pemakai atas kerugian yang mungkin dialami 


\section{Nominal: Barometer Riset Akuntansi dan Manajemen}

P-ISSN: 2303-2065 E-ISSN: 2502-5430

Volume 9 No 2 (2020)

karena menggunakan e-money, konsekuensi atas diperolehnya manfaat dari e-money. Pengukuran variabel ini memodifikasi instrument penelitian Diptha (2017) yang meliputi resiko yang ditinjau dari perspektif ekonomis, personal, kinerja organisasi, serta risiko privasi.

\section{Hipotesis}

Menurut beberapa hasil penelitian sebelumnya, diketahui bahwa salah satu alasan orang senang menggunakan e-money adalah karena transaksi pembayaran menjadi lebih nyaman bila dibandingkan bertransaksi dengan menggunakan uang tunai atau kartu debit. Menggunakan uang tunai terdapat resiko keamanan dan kesalahan, sedangkan dengan kartu debit diperlukan sandi sehingga kurang praktis. Kenyamanan atau kebermanfaatan pemakaian e-money timbul karena ketika bertransaksi menjadi lebih praktis, efisien dan aman. Banyaknya manfaat yang dirasakan pemakai kartu pembayaran elektronis ini menyebabkan persepsi yang baik terhadap pemakaian $e$ money meningkat.

\section{Technology Acceptance Model (TAM)} menyatakan bahwa perceived usefulness yang selanjutnya disebut sebagai kegunaan atau kebermanfaatan didefinisikan sebagai sejauh mana seseorang percaya bahwa menggunakan suatu teknologi akan meningkatkan kinerja pekerjaannya.
Kebermanfaatan merupakan variabel yang paling signifikan dan penting yang mempengaruhi sikap, intensi dan perilaku. Hasil penelitian Fadhli dan Fachruddin (2016) mendukung penelitian Idris (2013) menyimpulkan bahwa terjadi pengaruh positif signifikan persepsi manfaat terhadap penggunaan internet banking. Berdasarkan uraian di atas dapat dikembangkan sebuah hipotesis sebagai berikut,

$H_{l}$ : Persepsi kebermanfaatan berpengaruh positif terhadap persepsi pemakaian emoney

Kemudahan adalah aspek yang penting dalam mempengaruhi persepsi nasabah dalam penggunaan e-money. Hal ini dikarenakan semakin mudah suatu hal digunakan maka persepsi dalam menggunakan hal itu akan semakin baik. Apabila konsumen merasa suatu produk mudah digunakan maka mereka akan cenderung senang untuk memakai produk. Kemudahan penggunaan didefinisikan sebagai sejauh mana orang percaya bahwa menggunakan suatu teknologi akan bebas dari usaha. Variabel kemudahan dalam TAM, mempengaruhi variabel kegunaan, sikap, intensi dan penggunaan teknologi sesungguhnya. Hasil penelitian Diptha (2017) menunjukkan ada pengaruh positif signifikan persepsi kemudahan terhadap penggunaan uang elektronik berupa kartu Flazz BCA di Kota Bali. Fadhli dan 


\section{Nominal: Barometer Riset Akuntansi dan Manajemen}

P-ISSN: 2303-2065 E-ISSN: 2502-5430

Volume 9 No 2 (2020)

Fachruddin (2016) juga mengatakan bahwa ada pengaruh persepsi kemudahan terhadap penggunaan internet banking di Kota Banda Aceh. Penjelasan di atas menjadi landasan untuk hipotesis kedua berikut ini,

\section{$\mathrm{H}_{2}$ : Persepsi kemudahan penggunaan} berpengaruh positif terhadap persepsi pemakaian e-money

Diketahui bahwa faktor kepercayaan erat kaitannya dengan persepsi risiko, karena seseorang tidak akan mempercayai suatu hal apabila merasa bahwa risiko yang masih mungkin terjadi cukup besar. Maka semakin tinggi kepercayaan yang dimiliki oleh pengguna dapat mengurangi rasa ketidaknyamanan mereka terhadap risiko yang mungkin timbul. Semakin tinggi kepercayaan yang ada dalam diri setiap pengguna terhadap penggunaan e-money, maka pengguna tersebut akan memberikan persepsi yang baik dan terus menggunakan $e$ money sebagai alat transaksi utama. Dalam model TAM, kepercayaan dipengaruhi oleh risiko. Variabel kepercayaan, terdiri dari dua indikator, yaitu sistem keamanan dan sistem kerahasiaan (Koufaris \& Hampton-Sosa, 2004). Jika pengguna merasa bahwa risiko dari penggunaan suatu produk dalam hal keamanan dan kerahasiaan data, maka pengguna akan merasa percaya untuk menggunakan produk tersebut. Kepercayaan merupakan salah satu variabel yang akan mempengaruhi persepsi penggunaan suatu produk oleh penggunanya. Hasil penelitian Sekarini et al. (2016) menunjukkan kepercayaan konsumen secara positif signifikan berpengaruh terhadap penggunaan E-Toll di Kota Semarang. Berdasarkan uraian di atas dapat disusun hipotesis sebagai berikut,

H3: Kepercayaan berpengaruh positif terhadap persepesi pemakaian e-money

Risiko didefinisikan sebagai perkiraan subjektif individu untuk mendapatkan konsekuensi kerugian dalam menerima suatu hasil yang diinginkannya. Adanya beberapa kelemahan yang dimiliki oleh e-money menjadikan faktor penghambat dalam pengadopsian dala $e$-money serta efektifitas penggunaan e-money. Apabila pengguna merasa berisiko terhadap penggunaan suatu sistem, maka akan menimbulkan persepsi buruk bagi penggunanya. Risiko dapat dipengaruhi oleh perasaan positif atau negatif dari seseorang jika seseorang akan melakukan suatu tindakan atau ketika seseorang akan menggunakan suatu barang baru yang belum pernah digunakan. Dalam model TAM, risiko berpenngaruh pada intensi, serta dipengaruhi oleh kepercayaan. Hasil penelitian Fadhli dan Fachruddin (2016) menunjukkan risiko secara signifikan berpengaruh negatif terhadap penggunaan internet banking di kota Banda Aceh. Diptha (2017) menyatakan bahwa resiko memiliki pengaruh negatif terhadap kepuasan pegawai 


\section{Nominal: Barometer Riset Akuntansi dan Manajemen}

P-ISSN: 2303-2065 E-ISSN: 2502-5430

Volume 9 No 2 (2020)

terhadap penggunaan e-money $\mathrm{BCA}$ (Flazz BCA). Selanjutnya Sekarini et al., (2016) menjelaskan bahwa resiko memiliki pengaruh negatif signifikan terhadap keputusan pembelian dan penggunaan E-Toll di Semarang. Kajian dan penjelasan di atas digunakan untuk melandasi pengembangan hipotesis berikutnya, yaitu:

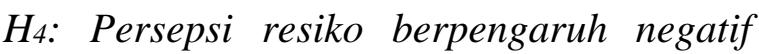
terhadap persepsi pemakaian e-money

\section{METODE PENELITIAN}

Populasi studi ini adalah masyarakat Kabupaten Sleman DIY usia produktif (kategori usia 15 - 65 tahun) yang berdasarkan data BPS Kabupaten Sleman tahun 2018 berjumlah 732.433 orang. Responden ditentukan dengan menggunakan metode sampel konfenien random dengan kriteria responden adalah populasi yang telah menggunakan e-money.

Penentuan jumlah sampel mengacu pada Hair et al. (1995) dimana bagi teknik analisis regresi berganda maka jumlah sampel minimal yang harus diambil adalah 15 hingga 20 kali jumlah variabel penelitian. Apabila terdapat 5 variabel penelitian; maka minimal sampel yang digunakan berjumlah (5 variabel $\times 20)=100$ sampel (minimal). Penelitian ini berhasil mengumpulkan data yang berasal dari 174 responden, akan tetapi data yang memenuhi syarat untuk diolah lebih lanjut berjumlah 132 sampel. Sejumlah
42 data tidak bisa digunakan karena 40 responden tidak memenuhi kriteria sample dan 2 responden tidak mengisi informasi dengan lengkap.

Data diperoleh dengan menyebarkan kuesioner melalui google form atau langsung diberikan peneliti/kurir kepada responden secara random ke beberapa kantor, mall dan SMA di wilayah Kabupaen Sleman. Penyebaran dilakukan selama bulan Maret 2018. Kuesioner menerapkan skala likert 5, dimulai dengan 1 sangat tidak setuju dan terakhir 5 sangat setuju. Penelitian ini merupakan penelitian kuantitatif dengan alat uji statistic SPSS. Pengujian yang dilakukan adalah uji statistik deskriptif, uji kualitas data: uji validitas dan reliabilitas, uji asumsi klasik dan uji hipotesis serta uji goodness of fit. Hipotesis diuji dengan menggunakan regresi linier berganda seperti model dibawah ini:

$\mathrm{Y}=\mathrm{a}+\mathrm{b}_{\mathrm{i}} \mathrm{X}_{\mathrm{i}}+\mathrm{b}_{2 \mathrm{i}} \mathrm{X}_{2 \mathrm{i}}+\mathrm{b}_{3 \mathrm{i}} \mathrm{X}_{3 \mathrm{i}}+\mathrm{b}_{4 \mathrm{i}} \mathrm{X}_{4 \mathrm{i}}+e$

Persamaan regresi setelah pengolahan data menghasilkan persamaan sebagai berikut: $Y=1,301+0,314 X 1+0,302 X 2+0,157 X 3$ $-0,201 X 4+0,451$

Keterangan:

$\mathrm{Y}=$ Persepsi pemakaian $e$-money

$\mathrm{a}=$ Konstanta

$\mathrm{b}_{1 \mathrm{i} . .4 \mathrm{i}}=\quad$ Koefisien regresi $\mathrm{X}_{1 \mathrm{i}}, \mathrm{X}_{2 \mathrm{i}}, \mathrm{X}_{3 \mathrm{i}}, \mathrm{X}_{4 \mathrm{i}}$

$\mathrm{X}_{1 \mathrm{i}}=$ Persepsi kebermanfaatan

$\mathrm{X}_{2 \mathrm{i}}=$ Persepsi kemudahan penggunaan

$\mathrm{X}_{3 \mathrm{i}}=$ Kepercayaan terhadap e-money

$\mathrm{X}_{4 \mathrm{i}}=$ Persepsi resiko

$e=$ Random error 


\section{HASIL PENELITIAN DAN PEMBAHASAN}

Sampel penelitian ini diperoleh dari 132 responden yang berasal dari 10 kecamatan (60\%) dari keseluruhan 17 kecamatan di Kabupaten Sleman. Sebaran responden menurut domisili dan gender disajikan pada Tabel 1. Selanjutnya, hasil analisis deskriptif variabel penelitian disajikan pada Table 2 .

Tabel 1. Profil Responden Menurut Domisili dan Gender

\begin{tabular}{|c|c|c|c|c|}
\hline \multirow{3}{*}{$\begin{array}{l}\text { Kecamatan } \\
\text { 1. Depok }\end{array}$} & \multirow{3}{*}{$\begin{array}{l}\text { Gender } \\
\text { Laki-laki } \\
\text { Perem }\end{array}$} & \multirow{3}{*}{$\begin{array}{r}\text { Jml } \\
7 \\
17\end{array}$} & \multicolumn{2}{|c|}{$\%$} \\
\hline & & & $5 \%$ & 180 \\
\hline & & & $13 \%$ & $10 \%$ \\
\hline \multirow{2}{*}{ 2. Godean } & Laki-laki & 5 & $4 \%$ & \multirow{2}{*}{$9 \%$} \\
\hline & Perem & 7 & $5 \%$ & \\
\hline \multirow{2}{*}{ 3. Kalasan } & Laki-laki & 5 & $4 \%$ & \multirow{2}{*}{$6 \%$} \\
\hline & Perem & 2 & $2 \%$ & \\
\hline \multirow{2}{*}{ 4. Mlati } & Laki-laki & 9 & $7 \%$ & \multirow{2}{*}{$9 \%$} \\
\hline & Perem & 2 & $2 \%$ & \\
\hline \multirow{2}{*}{ 5. Ngaglik } & Laki-laki & 10 & $8 \%$ & \multirow{2}{*}{$17 \%$} \\
\hline & Perem & 12 & $9 \%$ & \\
\hline \multirow{2}{*}{$\begin{array}{l}\text { 6. Ngem } \\
\text { plak }\end{array}$} & Laki-laki & 2 & $2 \%$ & \multirow{2}{*}{$11 \%$} \\
\hline & Perem & 9 & $7 \%$ & \\
\hline \multirow{2}{*}{ 7. Pakem } & Laki-laki & 2 & $2 \%$ & \multirow{2}{*}{$7 \%$} \\
\hline & Perem & 6 & $5 \%$ & \\
\hline \multirow{2}{*}{ 8. Sleman } & Laki-laki & 10 & $8 \%$ & \multirow{2}{*}{$12 \%$} \\
\hline & Perem & 5 & $4 \%$ & \\
\hline \multirow{2}{*}{ 9. Tempel } & Laki-laki & 6 & $5 \%$ & \multirow{2}{*}{$12 \%$} \\
\hline & Perem & 6 & $5 \%$ & \\
\hline \multirow{2}{*}{ 10. Turi } & Laki-laki & 8 & $6 \%$ & \multirow{2}{*}{$10 \%$} \\
\hline & Perem & 2 & $2 \%$ & \\
\hline \multirow{3}{*}{\multicolumn{2}{|c|}{$\begin{array}{l}\text { Jumlah Laki-laki } \\
\text { Jumlah Perempuan } \\
\text { Jumlah Responden }\end{array}$}} & 64 & $48 \%$ & \\
\hline & & 68 & $52 \%$ & \\
\hline & & 132 & $100 \%$ & \\
\hline
\end{tabular}

Uji validitas terhadap setiap variable menghasilkan nilai yang valid pada setiap indikatornya, yaitu nilai $\mathrm{r}$ hitung $>\mathrm{r}$ tabel. Selanjutnya, dihasilkan nilai Cronbach alpha $>0,60$ dari setiap variable dari pengujian reliabilitas; artinya kualitas data yang diolah dapat diandalkan. Hasilnya disajikan pada Tabel 3.

Tabel 2. Analisis Deskriptif Variabel

Penelitian

\begin{tabular}{|c|c|c|c|c|c|}
\hline Variabel & $\mathbf{n}$ & $\begin{array}{c}\mathbf{M i} \\
\mathbf{n}\end{array}$ & $\begin{array}{c}\text { Ma } \\
\text { x }\end{array}$ & $\underset{\mathbf{n}}{\text { Mea }}$ & $\begin{array}{l}\text { Std. } \\
\text { Dev }\end{array}$ \\
\hline $\begin{array}{l}\text { Persepsi } \\
\text { Keberanfaat } \\
\text { an }\end{array}$ & 132 & 1,0 & 5,0 & 3,79 & 0,88 \\
\hline $\begin{array}{l}\text { Persepsi } \\
\text { Kemudahan } \\
\text { Penggunaan }\end{array}$ & 132 & 1,0 & 5,0 & 3,89 & 0,95 \\
\hline Kepercayaan & 132 & 1,0 & 5,0 & 3,95 & 0,82 \\
\hline $\begin{array}{l}\text { Persepsi } \\
\text { Resiko }\end{array}$ & 132 & 1,0 & 5,0 & 2,24 & 0,97 \\
\hline $\begin{array}{l}\text { Persepsi } \\
\text { Pemakaian } \\
\text { e-money }\end{array}$ & 132 & 1,0 & 5,0 & 3,84 & 0,89 \\
\hline Valid n & 132 & & & & \\
\hline
\end{tabular}

Tabel 3. Hasil Uji Reliabilitas Data

\begin{tabular}{lc}
\hline \multicolumn{1}{c}{ Variabel } & Cronbach Alpha \\
\hline Persepsi & 0,840 \\
Kebermanfaatan & \\
Persepsi Kemudahan & 0,924 \\
Penggunaan & \\
Kepercayaan & 0,836 \\
Persepsi Resiko & 0,841 \\
Persepsi Pemakaian & 0,888 \\
\hline
\end{tabular}

Uji normalitas data dilakukan dengan uji

Kolmogorov-Smirnov menghasilkan semua kriteria terpenuhi, Tabel 4 memperlihatkan hasilnya. Uji Kolmogorov-Smirnov bernilai 0,753 dan signifikansi 0,622 .

Selanjutnya Tabel 5 dapat menjelaskan bahwa model penelitian bebas dari multikolineritas karena tolerance value setiap variabel $>0,10, \mathrm{VIF}<10$. Demikian juga dapat dilihat bahwa model tidak memiliki masalah heteroskedastisitas, signifikansi semua variabel bebas $>0,05$.

Tabel 4. Hasil Uji Normalitas 


\begin{tabular}{lcc}
\hline \multicolumn{1}{c}{ Uji } & Perhitungan & Unstandardized \\
\hline Normal & Mean & 0,0000 \\
Parameter & Standart & 0,4438273 \\
& $\begin{array}{c}\text { Deviation } \\
\text { Absolute }\end{array}$ & 0,066 \\
Extreme & & \\
Difference & Positive & 0,047 \\
& Negative & $-0,066$ \\
Kolmogoro- & & 0,753 \\
Smirnov Z & & 0,622 \\
Asymp. & & \\
Sig.(2tailed) & & \\
\hline
\end{tabular}

Tabel 5. Hasil Uji Multikolinieritas dan Heteroskedastisitas

\begin{tabular}{|c|c|c|c|}
\hline \multirow{2}{*}{$\begin{array}{c}\text { Variabel } \\
\text { Bebas }\end{array}$} & \multicolumn{2}{|c|}{$\begin{array}{c}\text { Uji } \\
\text { Multikolinie } \\
\text { ritas }\end{array}$} & \multirow{2}{*}{$\begin{array}{c}\text { Uji } \\
\text { Heteroske } \\
\text { das tisitas } \\
\text { Sig. }\end{array}$} \\
\hline & $\begin{array}{l}\text { Toler } \\
\text { ance }\end{array}$ & VIF & \\
\hline $\begin{array}{l}\text { Persepsi } \\
\text { Kebermanfaa } \\
\text { tan }\end{array}$ & 0,463 & 2,16 & 0,115 \\
\hline $\begin{array}{l}\text { Persepsi } \\
\text { Kemudahan } \\
\text { Penggunaan }\end{array}$ & 0,335 & 2,98 & 0,515 \\
\hline Kepercayaan & 0,459 & 2,18 & 0,213 \\
\hline $\begin{array}{l}\text { Persepsi } \\
\text { Resiko }\end{array}$ & 0,397 & 2,52 & 0,424 \\
\hline
\end{tabular}

Tabel 6. Hasil Uji Hipotesis

\begin{tabular}{lccc}
\hline \multicolumn{1}{c}{$\begin{array}{c}\text { Variabel } \\
\text { Independen }\end{array}$} & $\begin{array}{c}\text { Koefisien } \\
\text { Regresi }(\boldsymbol{\beta})\end{array}$ & $\begin{array}{c}\text { T } \\
\text { hitung }\end{array}$ & $\begin{array}{c}\text { Proba } \\
\text { bilitas }\end{array}$ \\
\hline $\begin{array}{l}\text { Konstanta } \\
\text { Persepsi }\end{array}$ & 1,301 & & \\
$\begin{array}{l}\text { Kebermanfaatan } \\
\text { (X1i) }\end{array}$ & 0,314 & 4,766 & 0,000 \\
$\begin{array}{l}\text { Persepsi } \\
\text { Kemudahan } \\
(X 2 i)\end{array}$ & 0,302 & 4,224 & 0,000 \\
$\begin{array}{l}\text { Kepercayaan } \\
\text { (X3i) }\end{array}$ & 0,157 & 2,202 & 0,029 \\
$\begin{array}{l}\text { Persepsi Resiko } \\
(X 4 i)\end{array}$ & $-0,201$ & 3,124 & 0,002 \\
\hline
\end{tabular}

Tabel 6 menyajikan hasil dari uji hipotesis melalui persamaan linier berganda. Dengan tingkat signifikansi $\alpha=5 \%$; maka diketahui bahwa semua hipotesis penelitian (Hipotesis 1, 2, 3, dan 4) didukung oleh data. Hasil ini ditunjukkan pada Tabel 6 bahwa semua nilai Probabilitas $<0,05$.

Penjelasan atas hasil uji regresi yang ditunjukkan dalam Tabel 6 adalah: variabel persepsi kebermanfaatan, persepsi kemudahan penggunaan, dan kepercayaan memiliki pengaruh positif sinifikan terhadap variabel persepsi pemakaian e-money, sedangkan persepsi resiko memiliki pengaruh negatif signifikan terhadap persepsi pemakaian $e$-money.

Hipotesis pertama menyatakan bahwa persepsi kebermanfaatan e-money memiliki pengaruh positif terhadap minat pemakaian e-money. Kebermanfaatan e-money mudah dirasakan pemakai karena transaksi pembayaran menjadi lebih simpel, efisien dan dirasa lebih aman. Semakin banyak manfaat yang dirasakan oleh pemakai ditandai dengan semakin terpenuhinya kebutuhan pemakai maka akan meningkatkan persepsi yang baik terhadap pemakaian e-money. Hal ini berarti, apabila diketahui bahwa e-money memiliki banyak manfaat dibandingkan dengan uang tunai atau alat pembayaran lainnya, maka masyarakat akan semakin berminat menggunakan e-money. Kesimpulan ini mendukung hasil penelitian Fadhli dan Fachruddin (2016) bahwa persepsi kebermanfaatan terbukti memberikan 


\section{Nominal: Barometer Riset Akuntansi dan Manajemen}

P-ISSN: 2303-2065 E-ISSN: 2502-5430

Volume 9 No 2 (2020)

pengaruh positif terhadap persepsi pemakaian e-banking oleh nasabah bank di Banda Aceh.

Hipotesis kedua menyatakan bahwa persepsi kemudahan penggunaan e-money berpengaruh positif terhadap perspesi pemakaian e-money. Seorang pemakai akan merasa mudah karena ketika e-money digunakan tidak ditemui kesulitan. Kemudahan penggunaan bukan hanya dirasakan konsumen pada saat menggunakan e-money, akan tetapi juga pada waktu pertamakali melakukan aktifasi penggunaan e-money. Kemudahan penggunaan dapat mengurangi usaha, waktu, dan tenaga para pemakai untuk mempelajari seluk beluk dalam bertransaksi menggunakan e-money. Intensitas penggunaan dan interaksi antara pengguna dengan system yang baru diterapkan dapat menunjukkan kemudahan penggunaan sistem tersebut. Maka dari itu jika sebuah layanan, dalam hal ini e-money dapat dengan mudah digunakan oleh para nasabah, akan mempengaruhi persepsi konsumen terhadap layanan tersebut, dalam kasus ini adalah e-money.

Kemudahan adalah aspek yang penting dalam mempengaruhi persepsi pemakaian $e$ money. Hal ini dikarenakan semakin mudah sesuatu dapat digunakan maka persepsi dalam menggunakan sesuatu tersebut akan semakin baik. Apabila konsumen merasa suatu produk mudah digunakan maka mereka akan cenderung menerima dengan baik untuk memakai produk tersebut. Hasil ini sesuai penelitian Diptha (2017) yang menyimpulkan adanya pengaruh positif signifikan kemudahan penggunaan terhadap kepuasan pemakai kartu Flazz BCA di kalangan karyawan Anantara Resort Seminyak Bali.

Selanjutnya, hasil penelitian ini mengkonfirmasi bahwa hipotesis ketiga: kepercayaan berpengaruh positif terhadap persepsi pemakaian e-money terdukung oleh data. Semakin tinggi kepercayaan dalam diri seseorang ketika menggunakan e-money, maka orang/pengguna tersebut akan terus memakainya sebagai alat transaksi. Kepercayaan dibutuhkan oleh pengguna teknologi informasi dalam rangka meningkatkan kinerja individu ketika melakukan aktivitas dalam organisasi ataupun aktivitas pribadi. Kepercayaan juga membantu pengguna untuk mengurangi kompleksitas sosial dalam menghadapi kemungkinan yang tidak diinginkan. Semakin tinggi kepercayaan yang dimiliki oleh pengguna akan dapat mengurangi rasa ketidaknyamanan mereka terhadap risiko yang mungkin timbul. Hasil ini sesuai dengan penelitiannya Sekarini et al., (2016) yang menyebutkan bahwa kepercayaan konsumen secara signifikan berpengaruh positif terhadap pengguaan E-Toll di Kota Semarang. Diptha (2017) juga mengatakan 
bahwa ada pengaruh positif signifikan kepercayaan terhadap kepuasan pengguna Flazz BCA di Bali.

Hasil penelitian ini juga membuktikan bahwa hipotesis ke empat yaitu resiko berpengaruh negatif terhadap persepsi pemakaian e-money didukung oleh data. Apabila persepsi resiko rendah akan menyebabkan persepsi yang baik untuk terus bertransaksi dengan alat pembayaran nontunai, dan juga sebaliknya persepsi risiko yang tinggi akan menimbulkan persepsi buruk bagi pengguna e-money, akibatnya akan menurunkan tingkat kepercayaan pengguna terhadap e-money. Ditemukannya beberapa kelemahan e-money menjadi faktor penghambat seseorang untuk mengadopsi $e$ money, selain itu juga menurunkan efektifitas penggunaannya. Apabila pengguna merasa beresiko terhadap penggunaan e-money, maka akan menimbulkan persepsi buruk pengguna terhadap $e$-money. Hasil ini sesuai dengan penelitian Fadhli dan Fachruddin (2016) yang menunjukkan bahwa persepsi terhadap risiko secara signifikan berpengaruh negatif terhadap persepsi penggunaan internet banking di kalangan nasabah bank umum di Kota Banda Aceh.

Berikutnya Tabel 7 menunjukkan nilai koefisien determinasi $\mathrm{R}^{2}$ sebesar 0,744 . Hasil tersebut dapat diartikan bahwa variabel independen penelitian ini dapat menjelaskan variabel dependen sebesar $74,4 \%$, sebuah nilai yang bagus.

Tabel 7. Hasil Uji Koefisien Determinasi

\begin{tabular}{cccc}
\hline $\mathbf{R}$ & $\begin{array}{c}\mathbf{R} \\
\text { Square }\end{array}$ & $\begin{array}{c}\text { Adjusted } \\
\text { R Square }\end{array}$ & $\begin{array}{c}\text { Std. Error of } \\
\text { the Estimate }\end{array}$ \\
\hline $0,867^{\mathrm{a}}$ & 0,752 & 0,744 & 0,45079 \\
\hline
\end{tabular}

Hasil pengujian Goodness of Fit atau uji kelayakan model (uji-F) bisa dilihat pada Tabel 8. Hasilnya menunjukkan besaran nilai F hitung 96,382 dengan nilai signifikasi $0,000<0,05$. Dapat disimpulkan bahwa variabel bebas penelitian ini, yaitu persepsi kebermanfaatan, persepsi kemudahan penggunaan, kepercayaan dan persepsi resiko layak untuk menguji variabel terikat persepsi pemakaian $e$-money.

Tabel 8. Hasil Uji F

\begin{tabular}{lccccc}
\hline Model & $\begin{array}{c}\text { Sum of } \\
\text { Square }\end{array}$ & Df & $\begin{array}{c}\text { Mean } \\
\text { Square }\end{array}$ & F & Sig. \\
\hline $\begin{array}{l}\text { Regress } \\
\text { ion }\end{array}$ & 78,31 & 4 & 19,58 & 96,4 & $0,000^{\mathrm{b}}$ \\
$\begin{array}{l}\text { Residua } \\
1\end{array}$ & 25,80 & 127 & 0,203 & & \\
Total & 104,12 & 131 & & & \\
\hline
\end{tabular}

\section{SIMPULAN DAN SARAN}

\section{Simpulan}

Berdasarkan hasil uji dan analisis data, penelitian ini menyatakan bahwa semua hipotesis terdukung. Dengan seting masyarakat non perkotaan yang memiliki infrastruktur, tingkat pendidikan yang lebih terbatas, serta budaya yang lebih tradisional dibandingkan masyarakat kota, hasil penelitian ini mengonfirmasi hasil penelitian 
sebelumnya yang dilakukan dengan seting masyarakat kota-kota besar di Indonesia. Masyarakat non-perkotaan ternyata telah menaruh kepercayaan kepada e-money karena telah merasakan manfaat dan kemudahan ketika menggunakannya. Masyarakat non-perkotaan juga telah memahami risikonya.

Hasil penelitian ini didukung dengan data bahwa pada tahun 2017 rata-rata setiap 1 orang penduduk Indonesia memakai 1,42 HP/telepon seluler (Setyowati, 2019). Selanjutnya, Setyowati (2019) menjelaskan bahwa dengan jumlah penduduk 262 juta jiwa, kepemilikan HP di Indonesia mencapai 371,4 juta (142\% dari total populasi). Data tersebut dapat diartikan bahwa rata-rata setiap penduduk Indonesia dimanapun domisilinya telah menggunakan HP, sementara itu diketahui bahwa HP digunakan masyarakat untuk mengakses transaksi keuangan yang berbasis internet. Akhirnya, penelitian ini menyimpulkan bahwa selain masyarakat perkotaan, masyarakat nonperkotaan juga memiliki persepsi yang baik dan menerima pemakaian e-money sebagai alat pembayaran. Dengan demikian program cash less society yang dicanangkan oleh pemerintah RI akan didukung sepenuhnya oleh masyarakat Indonesia.

\section{Keterbatasan Penelitian}

Utamanya bagi penelitian selanjutnya, beberapa keterbatasan dalam penelitian ini disarankan untuk diperbaiki. Beberapa keterbatasan tersebut diantaranya adalah:

1. Meskipun telah melebihi jumlah minimal sampel, jumlah responden yang berhasil diperoleh baru mencapai 132 orang, hal ini karena keterbatasan waktu dan dana penelitian.

2. Wilayah atau seting penelitian hanya meliputi 1 kabupaten.

3. Belum melihat penggunaan e-money dari perspektif lainnya, misalnya faktor promosi dan pemberian diskon, life style, perkembangan e-commerce dan lainnya.

\section{Kontribusi dan Saran}

Beberapa kontribusi dan saran yang bisa diberikan dari penelitian ini adalah:

1. Bagi pihak penerbit e-money, kepercayaan yang diberikan oleh masyarakat terhadap e-money harus direspon dengan peningkatan layanan serta mengurangi risiko atau dampak negatif $e$-money, seperti: penyalahgunaan kartu, bocornya kerahasiaan data, aturan yang merugikan pemakai, dan lain sebagainya.

2. Bagi pemerintah sebagai pihak yang mencanangkan ide cash less society maka diminta dukungan serta realisasinya, terutama dari sisi regulasi untuk berbagai kepentingan, misalnya bagi penerbit $e$ money, perlindungan konsumen, pengawasan penyelenggaraan e-money, dan perbaikan infrastruktur terutama 
pemenuhan ketersediaan dan kecepatan internet.

3. Bagi masyarakat sebagai pemakai harus bisa mengendalikan diri dari perilaku boros sebagai dampak dari pemakaian $e$ money, harus memahami segala risiko pemakaiannya, serta keterbatasan yang masih ada misalnya sinyal internet yang belum merata serta keberterimaan oleh merchant.

\section{DAFTAR PUSTAKA}

Akinola, O. S. (2012). Cashless Society, Problems and Prospects, Data Mining Research Potentials. International Journal of Computer Science and Telecommunications, 3(8), 49-55.

Aryanto, N. (2017, March 27). Masyarakat Harus Setop Ketergantungan pada Uang Tunai. Viva.Co.Id. https://www.viva.co.id/arsip/898253masyarakat-harus-setop-ketergantunganpada-uang-tunai

Davis, F. D. (1989). Perceived Usefulness, Perceived Ease Of Use, And User Acceptance of Information Technology. MIS Quarterly, 13(3), 319-339. https://doi.org/10.2307/249008

Davis, F. D., Bagozzi, R. P., \& Warshaw, P. R. (1989). User Acceptance of Computer Technology: A Comparison of Two Theoretical Models. Management Science, 35(8), 982-1003. https://doi.org/10.1287/mnsc.35.8.982

Diptha, K. A. S. (2017). Faktor-Faktor Yang Mempengaruhi Tingkat Kepuasan Karyawan Dalam Menggunakan Uang Elektronik Kartu Flazz Bca Di Lingkungan Anantara Seminyak Resort -
Bali. Jurnal Pendidikan Ekonomi Undiksha, $\quad 9(1), \quad 167$. https://doi.org/10.23887/jjpe.v9i1.20002

Fadhli, M., \& Fachruddin, R. (2016a). (Studi Empiris pada Nasabah Bank Umum di Kota Banda Aceh). Manfaat, Dan Kemudahan Penggunaan Terhadap Penggunaan Internet Banking. Jurnal Ilmiah Mahasiswa Ekonomi Akuntansi (JIMEKA), 1(2), 264-276.

Fadhli, M., \& Fachruddin, R. (2016b). Pengaruh Persepsi Nasabah Atas Risiko, Kepercayaan, Manfaat, dan Kemudahan Penggunaan Terhadap Pengguna Internet Banking (Studi Empiris pada Nasabah Bank Umum di Kota Banda Aceh). Jurnal Ilmiah Mahasiswa Ekonomi Akuntansi (JIMEKA), 1(2), 264-276.

Hair, J. F., Black, W. C., Babin, Barry, J., \& Rolph, A. (1995). Multivariate Data Analysis (Seventh). Pearson.

Hsu, M. H., \& Chiu, C. M. (2004). Predicting electronic service continuance with a decomposed theory of planned behaviour. Behaviour and Information Technology, 23(5), 359-373. https://doi.org/10.1080/01449290410001 669969

Idris, H. C. (2013). Analisis penggunaan uang elektronik. Diponegoro Journal of Management, 2(3), 1-11. http://ejournals1.undip.ac.id/index.php/dbr

Jogiyanto. (2007). Sistem Informasi Keperilakuan. Andi Offset.

Khakim, A. (2016). Pengaruh Persepsi Kemudahan, Persepsi Kemanfaatan dan Kelompok Referensi Terhadap Penggunaan Alat Pembayaran Menggunakan Kartu (APMK) (Studi Kasus Masyarakat Kabupaten Grobogan). Institut Agama Islam Negeri Salatiga. 
Koufaris, M., \& Hampton-Sosa, W. (2004). The development of initial trust in an online company by new customers. Information and Management, 41(3), 377-397.

https://doi.org/10.1016/j.im.2003.08.004

Peraturan Bank Indonesia No . 11 / 12 /PBI /2009 Tanggal 13 April 2009 tentang Uang Elektronik (Electronic Money). (2009). Pertaturan Perundang-Undangan Bank Indonesia.

Rafiq, M. (2008). Pengaruh Kepercayaan Konsumen Pada Merek Terhadap Loyalitas. Jurnal Manajemen Dan Keuangan, 6(2), 39-62.

Rizqiah, R. N., \& Lubis, A. T. (2017). Penerapan Internet Financial Reporting (IFR) Pada Bank Umum Syariah Di Indonesia. Jurnal Akuntansi Dan Keuangan Islam, 5(1), 63-81. https://doi.org/10.35836/jakis.v5i1.14

Sekarini, D. M., Sukresna, I. M., \& Ph, D. (2016). Analisis Pengaruh Persepsi Manfaat Dan Citra Merek Terhadap Keputusan Pembelian Melalui Persepsi Nilai Pelanggan Sebagai Intervening ( Studi pada Pengguna E-Toll card Tahun 2015 di Kota Semarang ). Diponogoro Journal of Management, 5(3), 1-13.

Setyowati, D. (2019, January 22). Dua Riset Sebut Go-Pay Dominasi Pasar Pembayaran Digital di Indonesia. Katadata.Com. https://katadata.co.id/berita/2019/01/22/ dua- riset-sebut-go-pay-dominasi-pasarpembayaran-digital-di-indonesia 